\title{
MAGNETIC RESONANCE IMAGING IN CERVICAL SPINAL CORD COMPRESSION
}

\author{
GIOVANNI GIAMMONA, SALVATORE GIUFFRIDA, SALVATORE GRECO, \\ CASIMIRO GRASSI, FRANCESCO LE PIRA
}

SUMMARY - In patients with cervical spondylotic myelopathy MRI sometimes shows increased signal intensity zones on the $T_{2}$-weighted images. It has been suggested that these findings carry prognostic significance. ${ }^{2}$ We studied 56 subjects with cervical spinal cord compression. Twelve patients showed an increased signal intensity (21.4\%) and a prevalence of narrowing of the AP-diameter (62\% vs 24\%). Furthemore, in this group, there was evidence of a longer mean duration of the symptoms and, in most of the patients, of more serious clinical conditions. The importance of these predisposing factors remains, however, to be clarified since they are also present in some patients without the increased signal intensity.

KEY WORDS: magnetic resonance imaging, cervical spondylotic myelopathy.

Ressonância magnética na compressão da medula cervical.

RESUMO - Em pacientes com mielopatia cervical espondilótica a ressonáncia magnética (RMN) as vezes mostra algumas zonas com sinal de maior intensidade nas imagens em $T_{2}$, que teriam significada prognóstico. Examinamos 56 pacientes com compressåo da medula cervical. Em 12 havia hiperintensidade $(21,4 \%)$ e maior incidência de estreitamento do diâmetro antero-posterior (62\% contra 24\%). Ainda, neste grupo se verificava duração média maior da sintomatologia e, na maior parte dos pacientes, sinais clínicos mais graves. Todavia, a importancia desses fatores deve ainda ser esclarecida, pois estăo presentes também em alguns pacientes que nåo apresentam a hiperintensidade.

PALAVRAS-CHAVE: ressonância magnética, mielopatia cervical espondilótica.

The value of magnetic resonance imaging (MRI) in the prognosis of outcome from surgery of subjects with cervical spondylotic myelopathy has been suggested by several authors $1-5$. The MRI shows increased signal intensity zones on the $\mathbf{T}_{2}$-weighted images in these patients. The aim of the present study is to verify the incidence and clinical correlations of these findings and also a possible pathogenesis.

\section{MATERIALS AND METHODS}

All the patients examined were suffering from symptoms and signs of cervical myelupathy. In all of them there was neuroradiological evidence of cervical spinal cord compression. We studied fifty-six inpatients by MRI with a 0.5 -Tesla superconducting magnet (Philips gyroscan). $T_{1}$ spin echo images with TRY 450 and TEA 30 and $T_{2}$-weighted images with

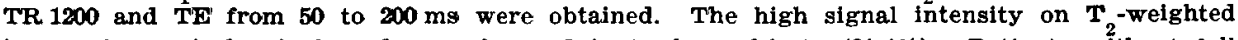
images in cervical spinal cord was observed in twelve subjects (21.4\%). Patients without full clinical data were excluded. Among the eleven cases left with altered signal we selected eight patients (group 1). Two of the excluded underwent decompressive surgery and the third had a cervical trauma. The control group, without altered signal, was made up of twenty-five

Institute of Clinical Neurology, University of Catania. Aceite: 2-março-1993.

Dott. Giovanni Giammona - Instituto di Clinica Neurologica, Policlínico dell' Universitá di Catania - Viale Andrea Doria 6 - 95125 Catania - Italia. Fax 39.95.330943. 
patients (group 2). We also examined age, sex, duration of symptoms, clinical data (we used a scale ranging from 0 to 3 ), type of compression (herniated disk or diskarthrosis) and spinal cord stenosis. Clinical data were assessed by a simple scale that examined pyramidal signs, motor and sentory disturbances. We gave one point for each of the three items. Therefore 0 means a negative neurological exam and 3 means the presence of all the three variables together. The AP-diameter of the spinal cord was measured and data compared with normal values reported by Sherman et al.6. Measurements were also obtained in areas with different signal intensity in the same subjects.

\section{RESULTS}

The two groups did not differ statistically as to age (group 1: $54 \pm 12.19$; group 2: $54.08 \pm 13.98$ ) and sex (group 1: 70\% males; group 2: 68\% males). Herniated disks were present in $62 \%$ of group 1 and $40 \%$ of group 2 without significant differences $(p \leqslant 0.497)$. There was a significant difference as regards the narrowing of the spinal cord (group 1: 62\%; group 2: $24 \% ; p \leqslant 0.1$ ) and duration of symptoms (group 1: $30.37 \pm 39.11$ months; group $2: 11.80 \pm 23.62 ; \mathrm{p} \leqslant 0.1)$. The minimum duration of symptoms was three months in group 1 . In the same group diskarthrosis was always associated with narrowing of the spinal cord. It was not determinant the level of the cervical compression. In all the patients in group 1 neurological signg were present while these signs were evident only in 52\% of the subjects of group 2. Comparing subjects of group 1 and those of group 2 with neurological signs it was possible to find a greater severity in those of group 1 (group 1: 2 points; group 2: 1.46).

\section{CoMmenTs}

Comparing our data with those of literature it is possible to find an incidence of altered signal findings very similar to that reported by Takahashi et al. $(18.88 \%)^{7}$. In their study, however, the incidence of herniated disk was higher than in ours. The importance of antero-posterior diameter of the spinal column and duration of symptoms has already been reported 1,7. Those rather important factors cannot, anyway, fully explain the abnormal signal. Six patients of group 2, in fact, had a long duration of symptoms and a severe compression of the spinal cord. Nevertheless, it is interesting that the clinical severity of these subjects was lower than those of group $1(1.33 \%)$. Thus, it is possible to suggest, together with unknown individual anatomical factors, that in the presence of spinal cord compression the duration of the compression itself plays a significant role. It is also evident that the duration of compression cannot be assumed only knowing the duration of clinical symptoms.

Conclusions. Though our data do not allow us to define pathogenetic reasons of an altered signal the duration of compression is without doubt important. It may be useful, then, in patients with increased signal intensity in $\mathrm{T}_{2}$-weighted images to consider a surgical decompression as soon as possible.

\section{REFERENCES}

1. La Tessa G, Cirillo S, Briganti F, Simonetti L, Giugliano V, Elefante R, Smaltino F. La risonanza magnetica nella mielopatia cervicale da compressione cronica. Rivista di Neuroradiologia 1989, 2:141-145.

2. La Tessa G, Spadetta F, Bucciero A, Quaglietta P, Tedeschi E, Elefante R, Tedeschi G, La RM nel controllo dei pazienti sottoposti ad intervento chirurgico per mielopatia da compressione cervicale cronica. Rivista di Neuroradiologia 1991, 4:177-181.

3. Matsuda $\mathbf{Y}$, Miyazaki K, Tada K, Yasuda A, Nikayama T, Murakami M, Matsuo M. Increased MR signal intensity due to cervical myelopathy: analysis of 29 surgical cases. J Neurosurg 1991, 74:887-892.

4. Mehalic TF, Pezzuti RT, Applebaum BI, Sypert GW. Magnetic resonance imaging and cervical spondylotic myelopathy. Neurosurgery 1990, 26:217-227.

5. Nagata $\mathbf{K}$, Kiyonaga $\mathbf{K}$, Ohashi $\mathbf{T}$, Sagara $\mathbf{M}$, Miyazaki $\mathbf{S}$, Inoue $\mathbf{A}$. Clinical value of magnetic resonance imaging for cervical myelopathy. Spine 1990, 15:1088-1096.

6. Sherman JL, Nassaux PY, Citrin CM. Measurements of the normal cervical spinal cord on MR imaging. Am J Neuroradiol 1990, 11:369-372.

7. Takahashi $M$, Sakamoto $Y$, Miyawaki $M$, Bussaka $H$. Increased MR signal intensity secondary to chronic cervical cord compression. Neuroradiology 1987, 29:550-556. 